\title{
CASUS
}

\section{Ontwikkelingen in de regelgeving omtrent beloningen}

\author{
Streng, strenger, strengst?
}

\author{
E.S. Sijmons
}

\section{Introductie}

Ruim vier jaar geleden trad de Wet beloningsbeleid financiële ondernemingen (Wbfo) in werking, waarmee een breed pakket aan beloningsregels is geïntroduceerd voor alle financiële ondernemingen. Het doel was een beheerst beloningsbeleid zonder perverse prikkels bij deze ondernemingen te bewerkstelligen. In 2018 is de Wbfo geëvalueerd, met voorgenomen wijzigingen tot gevolg. Daarnaast is vanuit politieke hoek een aantal voorstellen tot aanscherpingen gedaan als reactie op maatschappelijke ontwikkelingen. Dit artikel biedt een overzicht van de recente ontwikkelingen en beschouwt in hoeverre de nieuwe voorstellen en voorgenomen wijzigingen aansluiten bij de uitkomsten van de evaluatie van de Wbfo.

\subsection{Historie}

Voor de komst van de Wbfo waren er al maatregelen genomen ter bevordering van beheerst beloningsbeleid, zoals zelfregulering, de herziene richtlijn banken (CRD III), de introductie van het Besluit beheerst beloningsbeleid en de bijbehorende Regeling beheerst beloningsbeleid in 2011. De Europese regels werden verder geharmoniseerd en aangescherpt in onder meer de richtlijn kapitaaleisen (CRD IV) en andere sectorale richtlijnen, zoals de richtlijnen voor beheerders van alternatieve beleggingsinstellingen en beheerders van instellingen voor collectieve belegging in effecten, de verordening voor verzekeraars en de richtlijn voor beleggingsondernemingen. In aanvulling op de Europese beloningsregels besloot een aantal lidstaten om verdergaande regels te introduceren. Nederland was daar een van.

De beloningsregels die via de Wbfo in de Wet op het financieel toezicht (Wft) zijn opgenomen, beogen beloningen die medewerkers aanzetten tot het nemen van buitensporig hoge risico's aan banden te leggen, omdat dergelijke risico's tegenstrijdig kunnen zijn met langetermijnbelangen en de weerbaarheid van de onderneming alsmede met de klantbelangen. Ook diende de Wbfo de tot dat moment bestaande beloningsregelgeving voor financiële ondernemingen overzichtelijk 
samen te brengen, begrippen te harmoniseren en waar nodig destijds bestaande normen aan te scherpen. ${ }^{1}$

\subsection{Inhoud artikel}

In paragraaf 2 van dit artikel wordt een aantal belangrijke regels en uitzonderingen uit de Wbfo op een rijtje gezet. Daarbij zullen de belangrijkste punten waarop Nederland afwijkt van de Europese regels worden benoemd. In paragraaf $3 \mathrm{komt}$ de recente evaluatie van de Wbfo aan bod en wordt een aantal overige praktijkervaringen besproken. In paragraaf 4 komen recente nationale ontwikkelingen aan de orde waaronder een initiatiefwetsvoorstel om een instemmingsrecht van de minister van Financiën te introduceren met betrekking tot de vaste beloning van bestuurders van systeemrelevante banken en de mogelijke verdere inperking van de uitzondering op de bonuscap van $20 \%$ voor personen die buiten de cao vallen. ${ }^{2}$ Paragraaf 5 blikt vooruit op de nieuwe Europese richtlijn kapitaaleisen (CRD V) en de regels die daarin worden opgenomen over het beloningsbeleid van banken en bepaalde beleggingsondernemingen. Deze regels worden mogelijk op meer typen financiële ondernemingen toegepast in Nederland. Paragraaf 6 bevat afsluitende opmerkingen.

\section{Belangrijke regels en uitzonderingen uit de Wbfo}

\subsection{Reikwijdte Wbfo}

De Wbfo raakt meer ondernemingen dan alleen financiële ondernemingen. De Wbfo is namelijk van toepassing op alle financiële ondernemingen met zetel in Nederland alsmede hun dochterondernemingen. Daarnaast is het zo dat wanneer een financiële onderneming met zetel in Nederland behoort tot een groep in de zin van het Burgerlijk Wetboek (BW) en de aan het hoofd van die groep staande groepsmaatschappij eveneens haar zetel in Nederland heeft, de aan het hoofd van de groep staande groepsmaatschappij zorg moet dragen voor toepassing en naleving van de Wbfo binnen alle entiteiten in haar groep. Dit brede toepassingsbereik heeft bijvoorbeeld tot gevolg dat buitenlandse dochters van een in Nederland gevestigde bank in beginsel ook onder de reikwijdte van de Wbfo vallen. Verder valt op dat waar de Europese regels vooral gelden voor personen die een wezenlijke invloed kunnen hebben op het risicoprofiel van de onderneming, de Wbfo in beginsel geldt voor alle personen die werkzaam zijn onder verantwoordelijkheid van de onderneming.

De Wbfo dient in samenhang te worden gelezen met verschillende sectorale en nadere regelgeving en richtsnoeren, zoals de Regeling beheerst beloningsbeleid 2017, de EBA Richtsnoeren betreffende een beheerst beloningsbeleid (bij CRD IV) en de EIOPA Richtsnoeren voor het governancesysteem (bij Solvency II). Omwille van de beperkte omvang van deze bijdrage ligt de focus op de Wbfo.

1 Kamerstukken II 2013/14, 33964, 3, p. 1 en 2 (MvT).

2 Deze paragraaf beoogt overigens geen uitputtend overzicht te geven. 


\subsection{Belangrijke regels en uitzonderingen uit de Wbfo}

De Wbfo staat het meest bekend om de zogenaamde bonuscap van 20\%. De bonuscap heeft tot gevolg dat de variabele beloning ${ }^{3}$ die een financiële onderneming ${ }^{4}$ met zetel in Nederland toekent aan een natuurlijke persoon werkzaam onder haar verantwoordelijkheid ten hoogste $20 \%$ mag bedragen van de vaste beloning ${ }^{5}$ van die persoon op jaarbasis. Dit plafond is strenger dan de Europese regelgeving voorschrijft. In de CRD IV is een plafond van $100 \%$ opgenomen en met toestemming van de aandeelhouders geldt een maximum van $200 \%$. De Wbfo bevat een aantal uitzonderingen op deze $20 \%$ bonuscap. Kort samengevat mag de variabele beloning hoger zijn dan $20 \%$ van de vaste beloning van de betreffende persoon indien:

- het gemiddelde van de verhouding tussen de vaste en variabele beloningen van alle onder verantwoordelijkheid van de onderneming werkzame personen die hun werkzaamheden binnen Nederland verrichten en wier beloning niet uitsluitend uit een cao volgt niet meer dan $20 \%$ bedraagt en de betreffende variabele beloning niet meer dan $100 \%$ van de vaste jaarlijkse beloning bedraagt (niet-cao-uitzondering);

- de betreffende persoon zijn werkzaamheden hoofdzakelijk in een andere lidstaat uitoefent. In dat geval mag de variabele beloning maximaal $100 \%$ van de vaste beloning op jaarbasis bedragen (werkzaamheden buiten Nederland, in andere EER-lidstaat);

- de betreffende persoon zijn werkzaamheden in hoofdzaak uitoefent in een staat die geen lidstaat is. Indien aandeelhouders, eigenaren of leden van de financiële onderneming dit goedkeuren, kan de variabele beloning maximaal $200 \%$ van de vaste beloning op jaarbasis zijn (werkzaamheden buiten Nederland, buiten de EER);

- voor een periode van vijf aaneengesloten kalenderjaren ten minste $75 \%$ van alle onder verantwoordelijkheid van de financiële onderneming werkzame natuurlijke personen gedurende ten minste drie van die vijf jaren in hoofdzaak werkzaam waren buiten Nederland. In dat geval mag de variabele beloning maximaal $100 \%$ van de vaste beloning van de betreffende persoon bedragen (internationale holding);

- het gaat om een bijkantoor van een bank of beleggingsonderneming uit een andere staat, waarop de plafonds van de CRD IV reeds van toepassing zijn (in Nederland gelegen bijkantoren).

3 'Variabele beloning' is in de Wbfo gedefinieerd als het deel van de totale beloning dat geen vaste beloning is.

4 Dit bonusplafond geldt niet voor beheerders van beleggingsinstellingen, beheerders van icbe's en een hele specifieke groep handelaren voor eigen rekening. Deze entiteiten zijn per wet uitgezonderd van het bonusplafond.

5 'Vaste beloning' is in de Wbfo gedefinieerd als het deel van de totale beloning dat bestaat uit onvoorwaardelijke financiële of niet-financiële voordelen zoals uitgewerkt in het beloningsbeleid van de onderneming of in overeenkomsten ten behoeve van het verrichten van werkzaamheden voor de onderneming. 
Uit de memorie van toelichting bij de Wbfo blijkt dat wanneer - conform een van de voornoemde uitzonderingen - voor een variabele beloning tussen $100 \%$ en $200 \%$ wordt gekozen, de onderneming hiervan melding dient de doen bij de toezichthouder en haar overwegingen daaromtrent dient toe te lichten. De memorie van toelichting luidt dat toepassing van deze hogere plafonds zeer terughoudend dient plaats te vinden en uitsluitend dient te worden toegepast wanneer dit ten aanzien van individuele personen noodzakelijk wordt geacht.

Naast het bonusplafond van $20 \%$ bevat de Wbfo een aantal andere belangrijke regels, bijvoorbeeld:

- de verplichting om een schriftelijk beloningsbeleid te hebben dat is afgestemd op de aard, reikwijdte en complexiteit van de activiteiten van de onderneming, en ook procedures en maatregelen ter implementatie daarvan;

- de verplichting om zowel financiële als ten minste $50 \%$ niet-financiële criteria te hanteren als basis voor de variabele beloning;

- een verbod op gegarandeerde variabele beloningen;

- de mogelijkheid om onder bepaalde omstandigheden malus (aanpassing naar beneden voorafgaand aan uitkering) en clawback (terugvordering na uitkering) toe te passen op reeds toegekende variabele beloningen;

- beperkingen met betrekking tot sign-on bonussen, retentiebonussen en vertrekvergoedingen;

- publicatie- en informatieverplichtingen;

- een verbod op variabele beloning voor bepaalde personen binnen de financiële onderneming in geval van staatssteun;

- een verbod om constructies of methoden te hanteren die ontwijking van de in de Wbfo neergelegde regels (waaronder het bonusplafond) mogelijk maken.

\section{Evaluatie van de Wbfo en observaties uit de praktijk}

\subsection{Evaluatie Wbfo}

Als gevolg van een amendement van Kamerleden De Vries (VVD) en Van Hijum (CDA) diende de Wbfo al na drie jaar na inwerkingtreding te worden geëvalueerd. Deze evaluatie heeft in 2018 plaatsgevonden en het evaluatierapport ${ }^{6}$ is op 17 juli 2018 door de minister van Financiën naar de Tweede Kamer gestuurd. ${ }^{7}$ Bij de evaluatie is gekeken naar (1) de doeltreffendheid, (2) de neveneffecten en (3) de uitvoerbaarheid en de beloningspraktijk. Ten behoeve van de evaluatie is input gevraagd van betrokken partijen en deskundigen (zoals toezichthouders, financiële ondernemingen, advocaten en andere adviseurs en belangenorganisaties), is extern onderzoek gedaan door Stichting GXP, ${ }^{8}$ en zijn uitvragen gedaan door toezichthouders en brancheorganisaties onder vergunningplichtige marktpartijen.

6 Ministerie van Financiën, Rapportage: 'Evaluatie wet beloningsbeleid financiële ondernemingen', 2018.

7 Kamerstukken II 2017/18, 33964, 46 (brief van de minister van Financiën).

8 Stichting GXP is een onafhankelijke non-profit onderzoeksinstelling gevestigd te Utrecht. 
Wat betreft de doeltreffendheid van de Wbfo concludeert het evaluatierapport onder meer dat het effect van de Wbfo op het beloningsbeleid, de prikkelwerking en de cultuur binnen de onderneming beperkt is. De meerderheid van de respondenten signaleerde wel een over het algemeen positieve ontwikkeling in het beloningsbeleid in de financiële sector met minder perverse prikkels dan ten tijde van het ontstaan van de kredietcrisis. Er is volgens deze respondenten meer aandacht voor klantbelang binnen de organisaties. Vrijwel alle betrokkenen gaven echter aan dat de effecten van specifiek de Wbfo moeilijk te isoleren zijn, omdat in dezelfde periode ook andere wettelijke maatregelen zijn geïntroduceerd, zoals het provisieverbod, de bestuursrechtelijke algemene zorgplicht in de Wft, het toezicht op het productontwikkelingsproces, de bankierseed en aanscherping van vakbekwaamheidseisen. Wetenschappers toonden door een experiment aan dat de hoogte van het bonusplafond in beginsel de mate waarin risico wordt genomen wel beïnvloedt. Dit is echter niet aantoonbaar het geval wanneer sprake is van een werknemer voor wie de klant duidelijk zichtbaar is. Er waren ook respondenten die vooral negatieve effecten van de Wbfo beschreven: in hun perceptie stegen de vaste beloningen ${ }^{9}$ (daardoor minder flexibiliteit) en ontstond afvinkgedrag (check the box) in plaats van dat naar de geest van de wet wordt gehandeld. De meeste betrokkenen waren van oordeel dat de Wbfo niet heeft bijgedragen aan het vertrouwen in de financiële sector in brede zin en de bancaire sector in het bijzonder, omdat de Wbfo de nadruk legt op wat er niet goed is gegaan en de indruk wekt dat de sector het niet zelf kan oplossen. Dit is volgens deze respondenten een negatieve focus die leidt tot een negatief sentiment over de financiële sector, dat langer aanhoudt dan in andere ons omringende landen, hetgeen demotiverend werkt. Enkele betrokkenen stelden daarentegen juist dat de Wbfo de reputatie van de sector als 'beheerst' internationaal, met name in Europa, versterkt.

Wat betreft de neveneffecten van de Wbfo toont het evaluatierapport onder meer dat het bonusplafond invloed heeft op het vestigingsklimaat en als een belemmerende factor wordt beschouwd bij de overwegingen omtrent hervestiging als gevolg van de brexit. Het evaluatierapport noemt ook de gevolgen van de Wbfo voor fintech bedrijven en de mogelijkheid dat financiële ondernemingen met een zetel in Nederland door de Wbfo eerder geneigd zouden zijn uit te breiden in andere landen dan Nederland. Volgens het evaluatierapport is het beeld dat uit de gesprekken ontstaat over de gevolgen van de Wbfo voor de mogelijkheid om getalenteerd personeel aan te trekken, uiteenlopend. Enerzijds wordt naar voren gebracht dat het op lange termijn moeilijk kan worden om talenten en bedrijven naar Nederland te halen door de strengere regels. Sommige sleutelfuncties zouden moeilijk kunnen worden vervuld. Dit zou met name zichtbaar zijn bij het aantrekken van geschikte IT'ers, wat vooral voor banken met IT legacy-problemen urgent kan zijn. Op nationaal niveau vissen de fondsbeheerders en bepaalde handelaren voor eigen rekening - die uitgezonderd zijn van de bonuscap - in dezelfde

9 Dit beeld werd overigens ook geschetst met betrekking tot verzekeraars en kleinere banken in een artikel van Het Financieele Dagblad van 25 maart 2019: 'Verzekeraars negeren kritiek op topbeloningen'. 
vijver als bijvoorbeeld andere beleggingsondernemingen die zich wel met de bonuscap geconfronteerd zien. Anderzijds werd door respondenten naar voren gebracht dat een aantal grote Nederlandse financiële ondernemingen recentelijk buitenlandse bestuurders heeft aangetrokken en dat de bonus voor hen blijkbaar niet doorslaggevend was. Op basis van cijfers van de Europese Centrale Bank (ECB) over de vestiging van banken in Nederland en in concurrerende landen tot en met 2016 is niet op te maken dat het Nederlandse bonusplafond tot gevolg heeft gehad dat banken zich minder vaak in Nederland vestigen, maar zulke effecten zijn ook niet uit te sluiten. Ook cijfers over arbeidsmigratie tonen nog weinig evidente effecten. De recente invoering van de Wbfo maakt het moeilijk om hierover afdoende uitspraken te kunnen doen.

Wat betreft de uitvoerbaarheid van de Wbfo en de beloningspraktijk blijkt uit het evaluatierapport dat in de markt verschillend wordt gedacht over de uitvoerbaarheid van de Wbfo. Dat de Wbfo op een aantal punten een bredere reikwijdte en een strengere invulling heeft dan de Europese beloningsnormen, leidt volgens veel marktpartijen in de praktijk tot vragen over de samenloop van Nederlandse regels uit de Wbfo en de Europese regelgeving. Uitvoering van de Wbfo in het buitenland zou ook complex zijn in verband met lokale regelgeving. De groepsbrede toepassing van de regels blijkt voornamelijk voor grote en internationaal opererende organisaties een ingewikkelde aangelegenheid te zijn. Kleinere, nationaal opererende organisaties hebben eerder vragen over publicatieverplichtingen en proportionaliteit. Door meerdere marktpartijen is gesignaleerd dat de brede groep van personen die volgens de wettekst onder het bonusplafond valt - 'natuurlijke persoon werkzaam onder de verantwoordelijkheid van de financiële onderneming' - en bijvoorbeeld de formulering 'werkzaamheden in hoofdzaak uitvoeren in een andere staat' in de praktijk tot onduidelijkheid leiden over de toepasselijkheid van de het bonusplafond op specifieke personen. Ook wijkt de definitie van 'vaste beloning' zoals opgenomen in de Wbfo af van de definitie die wordt gehanteerd door de European Banking Authority (EBA) in haar Richtsnoeren over beheerst beloningsbeleid, ${ }^{10}$ waardoor bijvoorbeeld discussie is ontstaan over de vraag of een contractuele vertrekvergoeding als vast of variabel moet worden gekwalificeerd. Vrijwel alle marktpartijen hebben aangegeven dat zij de publicatieverplichting met betrekking tot het aantal personen dat een totale beloning van $€ 1$ miljoen of meer ontvangt en het jaarlijks aan personen uitgekeerde bedrag aan variabele beloning als een last ervaren die tijd, kosten en administratie met zich brengt.

In zijn begeleidende brief aan de Tweede Kamer vatte de minister van Financiën de conclusies van het rapport als volgt kort samen:

'De meest relevante bevindingen van de evaluatie en mijn vervolgstappen zijn de volgende. Het extern uitgevoerde onderzoek suggereert in algemene zin

10 Richtsnoeren betreffende een beheerst beloningsbeleid overeenkomstig artikel 74, lid 3, en artikel 75, lid 2, van Richtlijn 2013/36/EU en openbaarmaking overeenkomstig artikel 450 van Verordening (EU) 575/2013 (EBA/GL/2015/22). 
dat het bonusplafond van 20 procent bijdraagt aan minder risicovol gedrag. Misbruik van de wettelijke mogelijkheden tot afwijking van het bonusplafond is niet evident gebleken. Wel wil ik in mijn bredere overleg met de sector het gesprek aangaan over het gebruik van de mogelijkheid om af te wijken van het bonusplafond voor personeel dat buiten de CAO valt. Ik zal uw Kamer hierover uiterlijk eind 2018 berichten, tegelijkertijd met mijn bevindingen over de drie aanvullende wettelijke maatregelen met betrekking tot vaste beloningen die ik overweeg.'

De aanvullende maatregelen waarover wordt gesproken, worden behandeld in paragraaf 4.

\subsection{Observaties uit de praktijk}

Hierna belicht ik graag enkele zijdelingse opmerkingen uit het evaluatierapport. Dit doe ik aan de hand van observaties uit de praktijk.

In de praktijk rijzen er vaak vragen over de uitleg van de niet-cao-uitzondering, zoals besproken in paragraaf 2.2 hiervoor. Daarbij willen marktpartijen graag weten wie allemaal moet en mag worden meegeteld bij de berekening van de gemiddelde variabele beloning. De wettekst zelf zegt hier namelijk niets over en de memorie van toelichting bij het betreffende artikel evenmin. Om de geest van deze bepaling te achterhalen, zodat men daarnaar kan handelen, moet diep in de parlementaire geschiedenis worden gegraven. De middelingsregeling is tijdens het wetgevingsproces onderwerp van hevig debat geweest in de Tweede Kamer, die kritisch tegenover deze regeling stond. ${ }^{11}$ De minister van Financiën heeft destijds herhaaldelijk benadrukt (1) dat deze middelingsregeling bedoeld is om in uitzonderingsgevallen aan specialistisch personeel een bonus van meer dan $20 \%$ toe te kennen, en dat (2) op misbruik van deze bepaling streng zou worden toegezien en gehandhaafd. Als voorbeeld van misbruik werd vaak genoemd het kunstmatig aanvullen van de groep waarover het gemiddelde moet worden berekend. In de toelichting bij het wettelijk verbod op ontwijking van de beloningsregels ${ }^{12}$ staat daarom als voorbeeld genoemd dat het kunstmatig aanvullen van de groep nietcao-medewerkers als verboden ontwijking wordt beschouwd. Van het aangekondigde strenge toezicht op en handhaving van deze bepaling is de afgelopen jaren niet gebleken. De minister van Financiën heeft nu aangekondigd duidelijkheid te verschaffen over deze uitzondering (zie par. 4 hierna). Het lijkt mij inderdaad wenselijk dat de invulling van deze uitzondering niet meer uit verslagen van Kamerdebatten hoeft te worden afgeleid, maar gewoon uit de wettekst blijkt. Al zal het voor veel marktpartijen ook lastig zijn om deze uitzondering verder ingeperkt te zien en zullen zij hun beloningsbeleid nogmaals onder de loep moeten nemen.

In algemene zin merk ik op dat de beloningsregels in de praktijk een zogenaamde regulatory burden kunnen zijn voor organisaties. In het evaluatierapport wordt het

11 Handelingen II 2014/15, 33964, 14, item 6.

12 Art. 1:116 Wft. 
neveneffect van afvinkgedrag genoemd. Mogelijk brengen de regels zoveel specifieke (administratieve) verplichtingen mee, dat financiële ondernemingen alle capaciteit besteden aan het naleven van de letter van de wet en minder flexibiliteit hebben om te handelen in de geest van de regels. Dat kan paradoxaal genoeg leiden tot - vanuit regelgeving gezien - onwenselijk gedrag. Een veelheid van regels en de kosten gemoeid met de naleving daarvan kunnen leiden tot wat door de heren Van de Loo en Winter in het Tijdschrift voor Financieel Recht is beschreven als het regulatory crowding-out effect. Daarmee wordt bedoeld dat mensen en organisaties alleen nog zorgvuldig handelen op terreinen die zijn gereguleerd en waarop toezicht wordt uitgeoefend (omdat en voor zover de regels dat voorschrijven en daarop wordt gecontroleerd), en dat mensen hun vermogen om zelf morele afwegingen te maken niet meer aanspreken. De morele verantwoordelijkheid is als het ware uitbesteed aan degene die de regels maakt, zoals de compliance-afdeling of de externe toezichthouder, aldus deze auteurs. ${ }^{13}$ Het genoemde afvinkgedrag kan erin resulteren dat niet de beoogde intrinsieke cultuuromslag plaatsvindt op dit onderwerp, alle moeite ten spijt. Hierdoor zouden de beloningsregels hun doel voorbij kunnen schieten. Een voorbeeld van een regel die belastend kan werken voor zowel de organisatie als de toezichthouder - en die ook wordt genoemd in het evaluatierapport - is het voorschrift om voorafgaande schriftelijke instemming te krijgen van de toezichthouder voor een retentiebonus ${ }^{14}$ die meer dan $20 \%$ van de vaste beloning op jaarbasis van de betreffende persoon bedraagt. ${ }^{15}$ In de praktijk kan het gaan om een absoluut bedrag van enkele tienduizenden euro's, waarvoor in het geval van een significante bank die onder toezicht van de ECB staat, een medewerker van het joint supervisory team een schriftelijke nota dient op te stellen, vervolgens deze ter beoordeling dient voor te leggen aan het secretariaat van de Supervisory Board van de ECB, daarna ter goedkeuring aan de voorzitter of vicevoorzitter van de Supervisory Board en vervolgens aan de nationale toezichtdirecteuren (Supervisory Board) en de voorzitters van de nationale centrale banken (Governing Council) van alle lidstaten die deelnemen aan de Bankenunie. Dit kan uitmonden in een relatief dure exercitie voor een in absolute zin lage retentievergoeding. Bovendien dient de financiële onderneming ten minste rekening te houden met een formele instemmingstermijn van zes weken, wat in geval van een overnamescenario vrij lang is.

Een regel uit de Wbfo die zich mijns inziens goed leent als instrument voor het creëren van bewustwording en daarmee de beoogde cultuuromslag kan bewerkstelligen, is de regel dat het beloningsbeleid van de onderneming de criteria en prestaties dient te omvatten waarop de variabele beloning wordt gebaseerd. Het moet daarbij gaan om zowel financiële als ten minste $50 \%$ niet-financiële criteria en er dient te worden gekeken naar zowel de prestaties van de natuurlijke

13 E.L.M.H. van de Loo \& J.W. Winter, Extern toezicht op gedrag en cultuur: een paradoxale opgave?, FR 2019, afl. 1/2, p. 5 e.v.

14 Dit is geen officiële definitie, maar bedoeld wordt een variabele beloning in de zin van art. 1:122 Wft die noodzakelijk is in verband met een duurzame organisatiewijziging en strekt tot het behouden van de betreffende persoon voor de onderneming. 
persoon in kwestie als naar de prestaties van het bedrijfsonderdeel waar deze persoon werkzaam is en van de gehele onderneming. ${ }^{16}$ In de praktijk wordt ook wel gesproken van key performance indicators (KPIs). KPIs waaraan gemeten gaat worden, dienen voorafgaand aan de beoordelings- en beloningscyclus te worden gekozen of opgesteld en gedeeld te worden binnen de organisatie. Voorbeelden van persoonsgebonden niet-financiële KPIs zijn het op orde hebben van cliëntdossiers, de mate van compliancegerichtheid of de mate van performance op de leningen die deze persoon heeft uitgegeven aan klanten (wat een indicatie van de passendheid van het product is). Belangrijk is dat het gaat om doelen waar de persoon ook daadwerkelijk invloed op kan uitoefenen. Een voorbeeld van een niet-financiële KPI op het niveau van het bedrijfsonderdeel is de Net Promotor Score (waarmee klanttevredenheid wordt gemeten). Op niveau van de onderneming kan bijvoorbeeld worden gekeken naar de mate waarin strategische doelen behaald zijn binnen de grenzen van de vastgestelde risk appetite. ${ }^{17}$ In potentie kan de onderneming door het combineren van geschikte KPIs een gebalanceerde en maatschappelijk verantwoorde variabele beloning toekennen en binnen de onderneming mensen belonen die handelen in lijn met door de onderneming onderschreven (cultuur)principes. Hier is tevens een mogelijkheid gegeven voor de onderneming zelf om te bepalen waar de (cultuur)accenten gelegd worden. De toezichthouder heeft bevoegdheden om naar de vaststelling en toepassing van KPIs te kijken waar nodig. Het evaluatierapport gaat niet expliciet in op deze regel, maar bespreekt wel dat enkele respondenten erop wezen dat gedragsverandering kan plaatsvinden door sturing op sociale cohesie en door informele prikkels, waaronder het benoemen van goede voorbeelden.

\section{Recente nationale ontwikkelingen}

\subsection{Maatregelen voor vaste beloningen}

Tegelijk met de presentatie van het evaluatierapport in juli 2018 heeft het ministerie van Financiën een beleidsnota ${ }^{18}$ met een drietal maatregelen met betrekking tot regulering van vaste beloningen geconsulteerd. De volgende drie maatregelen worden overwogen:

1 'Introductie van de wettelijke verplichting tot terugvordering van een deel van de vaste beloning (boven een bepaald minimum) van bestuurders als er staatssteun aan een bank (of verzekeraar) wordt gegeven. Het doel van deze maatregel is om bestuurders meer persoonlijk verantwoordelijk te houden als de belastingbetaler (mede) opdraait voor verliezen van falende banken (of verzekeraars) (uitbreiding clawback);

16 Art. 1:118 Wft, gebaseerd op art. 94 CRD IV. Zie ook hoofdstuk 14 van de EBA Richtsnoeren betreffende een beheerst beloningsbeleid (EBA/GL/2015/22).

17 Hoofdstuk 14.1 van de EBA Richtsnoeren betreffende een beheerst beloningsbeleid geeft meerdere voorbeelden van beoordelingscriteria die kunnen worden gebruikt.

18 Het consultatiedocument en de reacties daarop kunnen worden geraadpleegd via www. internetconsultatie.nl/beloningsmaatregelenfinsector. 
2 Introductie van de wettelijke verplichting dat bestanddelen van een vaste beloning waarvan de waarde afhankelijk is van de marktwaarde van de eigen onderneming, zoals aandelen, bij bestuurders en medewerkers gedurende een nog te specificeren aantal jaren moeten worden aangehouden. Het doel van deze maatregel is om de belangen van de bestuurder en medewerkers meer in lijn te brengen met het lange termijn belang van de onderneming; en

3 Introductie van de wettelijke verplichting dat het beloningsbeleid van financiële ondernemingen voorschrijft op welke wijze de beloningen van bestuurders en medewerkers zich verhouden tot de maatschappelijke functie van de onderneming. Ondernemingen moeten zich hiervan in de openbaarheid rekenschap geven. Het doel van deze maatregel is om te bewerkstelligen dat financiële ondernemingen voor de totstandkoming van beloningsvoorstellen meer rekening houden met de maatschappelijke functie van de onderneming en zich hierover nadien verantwoorden.'

In de beleidsnota zelf wordt reeds benadrukt dat deze maatregelen niet in Europa voorkomen en mogelijk raken aan het recht op eigendom zoals neergelegd in het Eerste Protocol bij het Europees Verdrag tot bescherming van de rechten van de mens en de fundamentele vrijheden (EVRM). Ook wordt in de beleidsnota al in overweging gegeven dat de maatregelen met oog voor proportionaliteit dienen te worden vormgegeven en dat de mogelijke effecten op het investerings- en vestigingsklimaat van groot belang zijn. In consultatiereacties van advocatenkantoren en brancheorganisaties wordt onder meer opgemerkt dat:

- in algemene zin (1) de huidige wetgeving, de Herziene Aandeelhoudersrichtlijn, de Code Banken en de Corporate Governance Code al regels bevatten voor beleid omtrent vaste beloningen; (2) opnieuw wordt afgeweken van de Europese standaard; en (3) de regels te veel zijn gericht op systeemrelevante en/of beursgenoteerde ondernemingen, terwijl ook veel financiële ondernemingen in Nederland tot het MKB kunnen worden gerekend of behoren tot een generatie van fintechs die nog niet bestond ten tijde van de crisis;

- maatregel 1 (uitbreiding clawback) (1) strijdig is met art. 1 Eerste Protocol bij het EVRM en de vereiste rechtvaardiging voor de inbreuk ontbreekt, (2) niet strookt met het bestaande juridisch stelsel van 'vaste beloning' en 'loon' onder het Nederlands recht, (3) overbodig is in verband met de reeds bestaande mogelijkheden die verschillende wetten (BW en Wft) al bieden voor aansprakelijkheid van bestuurders in geval van onbehoorlijk bestuur en malus en clawback, ${ }^{19}$ (4) strijdig is met het rechtszekerheidsbeginsel en het evenredigheidsbeginsel, (5) een verdere beperking vormt van het level playing field en niet bevorderlijk is voor het vestigingsklimaat, en (6) de afdwingbaarheid ervan in andere jurisdicties (in verband met extraterritoriale reikwijdte van de Wbfo) mogelijk beperkt is door lokale regelgeving; 
- maatregel 2 (retentieperiode voor vaste beloning in aandelen) (1) onnodig is omdat de huidige wetgeving en de Corporate Governance Code reeds mogelijkheden bieden tot een retentieperiode ten aanzien van bestuurders en/of medewerkers wier werkzaamheden het risicoprofiel van de onderneming materieel kunnen beïnvloeden (Identified Staff), althans (2) bij het vormgeven van de regels aansluiting moet worden gezocht bij de bestaande regels indien deze maatregel wordt geïmplementeerd, en de werkingssfeer te beperken tot Identified Staff;

- maatregel 3 (rekenschap verhouding beloning tot maatschappelijke functie) onnodig is omdat het BW, de Wet op de ondernemingsraden (WOR), de Code Banken en de Corporate Governance Code al grondslag hiervoor bieden en bovendien de rol die financiële ondernemingen vervullen in de maatschappij an sich grondslag is voor de verstrekkende bestaande wet- en regelgeving en het intensieve toezicht zoals dat nu reeds van toepassing is.

Kortom, het schort op z'n minst aan een deugdelijke en/of vereiste onderbouwing van de rechtmatigheid en noodzaak van deze maatregelen, mede gezien het in de beleidsnota geformuleerde doel en de reeds bestaande regels en best practices. Het is ook goed denkbaar dat een dergelijke onderbouwing überhaupt niet haalbaar is met betrekking tot de eerste maatregel (inbreuk op eigendomsrecht) en dat deze daardoor geen doorgang kan vinden. Op basis van de uitkomsten van de evaluatie van de Wbfo lijken er geen valide aanleidingen te zijn voor deze nieuwe maatregelen. Uit de agenda voor de financiële sector van het ministerie van Financiën ${ }^{20}$ (zie par. 4.3 hierna) blijkt dat de Raad van State om advies is gevraagd met betrekking tot de eerste maatregel. ${ }^{21}$ De andere twee maatregelen zijn voor het kabinet nog niet van de baan. Het is afwachten hoe de wetsvoorstellen en motivering daarbij zullen luiden.

\subsection{Instemmingsrecht minister voor vaststelling of verhoging vaste beloning}

In maart 2018 presenteerde een aantal leden van de Tweede Kamer een initiatiefwetsvoorstel waarin een nieuwe definitie van 'vaste beloning' en een instemmingsrecht voor de minister van Financiën zijn opgenomen met betrekking tot de vaststelling of verhoging van de vaste beloning voor bestuurders van een systeemrelevante bank of haar Nederlandse holdingcompany. ${ }^{22}$ Dit initiatiefwetsvoorstel verscheen als reactie op de commotie omtrent de voorgestelde salarisverhoging van de CEO van ING Bank. De definitie van vaste beloning ${ }^{23}$ werd in het wetsvoorstel zodanig aangepast, dat aandelen in de onderneming of andere

Deze brief is te vinden op de website van de rijksoverheid: www.rijksoverheid.nl/documenten/ kamerstukken/2018/12/17/kamerbrief-agenda-financiele-sector.

21 De minister verwacht deze voorlichting van de Raad van State niet voor het eind van het eerste kwartaal van 2019. Ten tijde van het schrijven van deze bijdrage was er nog geen reactie van de Raad van State verschenen. Gezien het advies van de Raad van State omtrent het initiatiefwetsvoorstel (zie par. 4.2), acht ik de kans klein dat de Raad van State zal concluderen dat het voorstel voor de eerste maatregel legitiem is.

22 Kamerstukken II 2017/18, 34906, 2 (voorstel van wet).

23 Zoals opgenomen in art. 1:111 Wft. 
financiële instrumenten waarvan de waardestijging mede afhankelijk is van de waardestijging van aandelen in de onderneming of daaraan verbonden uitkeringen, niet onder 'vaste beloning' vallen. Dergelijke financiële instrumenten worden als gevolg van deze voorgestelde aanscherping aangemerkt als een bestanddeel van de variabele beloning, ten aanzien waarvan in beginsel het bonusplafond van $20 \%$ zou moeten gelden. In de praktijk zou het instemmingsrecht betekenen dat een voorstel van de raad van commissarissen over de vaste beloning van een bestuurder eerst aan de minister van Financiën dient te worden voorgelegd, alvorens de voorgenomen vaststelling of verhoging van de vaste beloning wordt voorgelegd aan de aandeelhoudersvergadering. Het initiatiefwetsvoorstel regelt verder dat de minister van Financiën zijn instemming weigert indien de hoogte van de vaste beloning naar het oordeel van de minister niet passend is met het oog op een zorgvuldig, beheerst en duurzaam beloningsbeleid dat kan rekenen op maatschappelijk draagvlak. Bij algemene maatregel van bestuur moeten volgens de initiatiefnemers nadere regels worden gesteld met betrekking tot de passendheid van de hoogte van een vaste beloning.

De Raad van State was kritisch over dit initiatiefwetsvoorstel. ${ }^{24}$ Ten aanzien van de wijziging van de definitie van 'vaste beloning' concludeerde de Raad van State dat de definitie is gebaseerd op Europese regelgeving en moet worden gelezen in het licht van de EBA Richtsnoeren voor beheerst beloningsbeleid. Vaste beloningen dienen in de eerste plaats een weerspiegeling te zijn van de relevante werkervaring en organisatorische verantwoordelijkheid. Vaste beloningen mogen als vast worden aangemerkt als zij geen prikkels geven voor het aangaan van risico's. In zoverre voegt het voorstel aan de al geldende regelingen niets toe. Waar het gaat om aandelenpakketten in de onderneming die worden verstrekt als beloning aan een bestuurder met daarbij de voorwaarde dat deze gedurende een bepaalde (langere) periode niet mogen worden verkocht, is het de Raad van State niet op voorhand duidelijk waarom daarvan perverse prikkels zouden uitgaan. Ten aanzien van het voorgestelde instemmingsrecht trok de Raad van State in zijn advies de conclusie dat het voorstel niet duidelijk maakt op welke wijze het effectief bijdraagt aan de stabiliteit van het financiële stelsel, terwijl de inbreuk die het voorgestelde instemmingsvereiste van de minister van Financiën maakt op het eigendomsrecht van de onderneming alleen is toegestaan indien daarvoor een zwaarwegende grond bestaat. Een dergelijke grond ontbrak vooralsnog in de toelichting bij het voorstel. De Raad van State overwoog dat op de naleving van de regels al toezicht wordt gehouden door de ECB in samenwerking met De Nederlandsche Bank (DNB). Uit de toelichting bij het wetsvoorstel blijkt niet waarom de bestaande regels en het bestaande toezicht door de bevoegde toezichthouder niet afdoende zouden zijn. Een beoordeling door de minister van Financiën doorkruist op ontoelaatbare wijze de bevoegdheid van de ECB, aldus de Raad van State. 
In vervolg op het advies van de Raad van State heeft de ECB op verzoek van het ministerie van Financiën geadviseerd over het wetsvoorstel. ${ }^{25}$ De ECB merkte op dat de ECB de exclusieve bevoegdheid heeft om met het oog op prudentieel toezicht specifieke taken te verrichten in verband met alle in de deelnemende lidstaten gevestigde kredietinstellingen, waaronder ook valt de beoordeling of kredietinstellingen beschikken over solide governanceregelingen, inclusief een beleid en een praktijk inzake beloningen conform de regelgeving. Het instemmingsrecht is op zich niet in strijd met de bevoegdheid van de ECB, mits de minister van Financiën niet beoordeelt of de kredietinstellingen voldoen aan hun verplichting om te beschikken over solide governanceregelingen, inclusief een conform(e) beloningsbeleid en -praktijk. In deze geest moet worden vermeden dat de eventuele algemene maatregelen van bestuur die de regels betreffende de passendheid van het bedrag van de vaste beloning detailleren, aanleiding geven tot een conflict met de toezichtsbevoegdheden van de ECB. Wat in feite gezegd wordt met dit advies is dat de minister er best iets van mag vinden, maar niet mag beoordelen of de voorgestelde beloning in lijn is met een beheerst $(e)$ beloningsbeleid en -praktijk, omdat dit nu eenmaal de bevoegdheid van de toezichthouder is. Ik kan mij moeilijk voorstellen dat de minister dan nog enige inhoudelijke toets kán doen of de beloning zorgvuldig, beheerst en duurzaam is, gelet op het maatschappelijk draagvlak. Door te oordelen dat een voorgestelde beloning daarmee in lijn is, oordeelt hij automatisch ook over de kwaliteit van het beleid op grond waarvan dit voorstel tot beloning tot stand is gekomen. Ofwel de minister vaart volledig op het oordeel van de toezichthouder, waarbij je je kunt afvragen wat dan de toegevoegde waarde is van zijn instemmingsrecht, ofwel de minister gaat op de stoel van de toezichthouder zitten, wat niet legitiem is.

Het kabinet heeft in zijn brief van 14 februari $2019^{26}$ de Tweede Kamer ontraden om het initiatiefwetsvoorstel aan te nemen. Kort samengevat, onderbouwde hij dit met het argument dat het voorstel op fundamentele bezwaren en aandachtspunten stuit en dat andere door het kabinet voorgestelde maatregelen passender en meer proportioneel zijn. ${ }^{27}$ Vlak voor indiening van deze kopij werd bekend dat bij een stemming in de Tweede Kamer geen meerderheid is bereikt voor dit initiatiefwetsvoorstel. ${ }^{28}$ Het voorstel is daarmee van tafel. Het wetsvoorstel en de overwegingen van de Raad van State, de ECB en het kabinet zijn echter illustratief

25 Advies van de Europese Centrale Bank van 23 oktober 2018 inzake de te volgen regels door systeemrelevante kredietinstellingen bij de vaststelling van het vastebeloningsbeleid (CON/ 2018/44).

26 Kamerstukken II 2017/18, 34906, 9 (brief van de minister van Financiën).

27 Het betreft (1) de introductie van een wettelijke verplichting voor financiële ondernemingen om aandelen en vergelijkbare instrumenten gedurende ten minste vijf jaren aan te houden, (2) de introductie van een wettelijke verplichting voor financiële ondernemingen om zich rekenschap te geven van en verantwoording af te leggen over de verhouding van de beloningen tot de functie van de onderneming in de sector en de positie in de samenleving, en (3) een aanscherping van de mogelijkheid tot afwijking van het bonusplafond voor niet-cao-personeel. Zie ook par. 4.3 hierna.

28 Zie Het Financieele Dagblad van 27 maart 2019. De coalitiepartijen en SGP stemden tegen het wetsvoorstel. 
voor het heersende sentiment en een mogelijke voorbode voor de juridische haalbaarheid van andere voorstellen omtrent vaste beloning.

\subsection{Agenda financiële sector}

Op 17 december 2018 publiceerde de minister van Financiën zijn Agenda financiële sector, waarin de belangrijkste maatregelen voor de financiële sector voor deze regeerperiode zijn aangekondigd. ${ }^{29}$ De minister focust zich in deze agenda op stabiliteit, integriteit en innovatie. Als onderdeel van de maatregelen op het gebied van integriteit en het tegengaan van excessief risicogedrag en veronachtzaming van het klantbelang is de minister van Financiën voornemens om de regels voor beloningsbeleid verder aan te scherpen door de in paragraaf 4.1 besproken maatregelen.

Daarnaast wordt de aanscherping van de mogelijkheid tot afwijking van het bonusplafond voor niet-cao-personeel genoemd. Deze aanscherping zal bestaan uit:

- de explicitering in de wet dat het gebruik van de uitzondering uitsluitend voor exceptionele gevallen mogelijk is, en in ieder geval niet voor personen die (1) interne controlefuncties verrichten en (2) zich rechtstreeks bezighouden met het verlenen van financiële diensten aan consumenten;

- de introductie van een wettelijke mededelingsplicht over het gebruik van de uitzondering door de financiële onderneming aan de toezichthouder; en

- het expliciete voornemen het gebruik van de uitzondering te betrekken in de evaluatie van de Wbfo over vijf jaar.

De aanscherping van de niet-cao-uitzondering is een maatregel die begrijpelijk is in het licht van de uitkomsten van de evaluatie van de Wbfo en observaties in de praktijk. Zoals gezegd, leidt die uitzondering in de praktijk regelmatig tot vragen over de reikwijdte ervan in verband met de ruime formulering en het gebrek aan duidelijke directe toelichting. De uitzondering lijkt tot nu toe in de markt breder te zijn geïnterpreteerd en toegepast dan alleen in uitzonderlijke gevallen. Hoewel niet genoemd in het evaluatierapport, bestaat het vermoeden dat in de markt ook wel misbruik wordt gemaakt van deze uitzondering door zo veel mogelijk personeelsleden buiten de cao te houden die ook geen variabele beloning krijgen, waardoor een kleine groep werknemers een hoge variabele beloning van tegen de $100 \%$ kan ontvangen. Wat opvalt is dat de uitzondering niet meer beschikbaar zal zijn voor medewerkers met klantcontact. Een in het kader van de evaluatie van de Wbfo verricht experiment van externe onderzoekers wees juist uit dat een hoger bonusplafond niet meetbaar bijdraagt aan meer risicovol gedrag voor werknemers met klantcontact. Ik ben daarom benieuwd naar de toelichting bij de verdere inkadering ten aanzien van dit specifieke punt.

Op het gebied van innovatie kondigt de minister aan dat het van belang is om proportionaliteit in regelgeving en toezicht te bevorderen om de kansen van fin- 
tech te benutten, en dat hij daarom in Europees en nationaal verband aandacht zal (blijven) vragen voor proportionaliteit, zowel bij nieuwe wetgevende initiatieven als bij bestaande regelgeving en in het toezicht. Dit sluit wel aan bij de bevinding uit de Wbfo-evaluatie dat de bestaande regels belemmerend kunnen werken voor het vestigingsklimaat en bij de roep van kleinere marktpartijen om proportionele toepassing van de regels.

\subsection{Wijziging WOR}

Overigens is met ingang van 1 januari 2019 de bepaling in de WOR omtrent overleg met de ondernemingsraad gewijzigd, waardoor in ondernemingen waarbij ten minste honderd personen werkzaam zijn, ten minste eenmaal per jaar in de overlegvergadering in ieder geval de hoogte en de inhoud van de regelingen en afspraken omtrent de beloning van werknemers, bestuurders en commissarissen worden besproken, evenals de ontwikkeling van de beloningsverhoudingen ten opzichte van het voorgaande jaar per groep van in de onderneming werkzame personen. Dit zou moeten bijdragen aan de bredere discussie over de passendheid van het gevoerde beloningsbeleid.

\section{Vooruitblik naar CRD V}

In 2016 heeft de Europese Commissie voorstellen gedaan voor de opvolger van de huidige richtlijn kapitaalvereisten (CRD IV) voor banken en bepaalde beleggingsondernemingen, wat de vijfde richtlijn kapitaalvereisten zal gaan worden (CRD V). De verwachting is dat (de implementatie van) het pakket van CRD V en de herziene verordening kapitaalvereisten (CRR II) pas in 2021 volledig van toepassing zal zijn. CRD V bevat een wijziging van de regels omtrent beloningsbeleid, waardoor een meer proportionele behandeling mogelijk wordt. De Nederlandse Regeling beheerst beloningsbeleid 2017 is grotendeels gebaseerd op CRD IV. De bonuscap uit CRD IV is door de nationale wetgever via de Wbfo ook toegepast op andere typen financiële ondernemingen. Het is daarom de vraag of CRD V breder zal worden toegepast dan alleen voor banken en bepaalde beleggingsondernemingen. Kort gezegd, zijn dit de meest relevante wijzigingen die CRD V introduceert voor beloningen:

- aanpassing met betrekking tot de groepsbrede en extraterritoriale toepassing van het beloningsbeleid binnen de onderneming;

- nadere uitwerking van het begrip Identified Staff (medewerkers wier werkzaamheden een materiële invloed kunnen hebben op het risicoprofiel van de onderneming);

- een wijziging met betrekking tot welke instrumenten kunnen worden gebruikt voor de verplichte minimale $50 \%$ van de variabele beloning die bestaat uit non-cashinstrumenten;

- verlenging van de minimale periode voor uitgestelde betaling van ten minste $40 \%$ van de variabele beloning voor Identified Staff naar vier jaar en voor bestuursleden en senior management van significante instellingen naar vijf jaar; 
- een proportionele behandeling voor kleinere instellingen.

De regels voor het uitbetalen van variabele beloning in non-cashinstrumenten, voor uitgestelde betaling en omtrent discretionary pension benefits bij vertrek van de werknemer voor het aanbreken van de pensioenleeftijd, zijn niet van toepassing op (1) kleine instellingen wier assets op individueel niveau niet meer bedragen dan $€ 5$ miljard, bezien over een periode van vier jaar voorafgaand aan het betreffende jaar, en (2) werknemers wier jaarlijkse variabele beloning niet meer dan $€ 50.000$ bedraagt en tegelijkertijd dit bedrag niet meer is dan een derde van de jaarlijkse vaste beloning van deze medewerker. Lidstaten mogen onder voorwaarden hiervan afwijken.

De invoering van een proportionele behandeling van kleine instellingen sluit aan bij de behoefte in de markt naar meer duidelijkheid over hoe kleine ondernemingen de soms verstrekkende of specifieke regels dienen te implementeren. Een kleine niet-beursgenoteerde onderneming kan bijvoorbeeld zeer geholpen zijn bij verval van de voorschriften om de helft van de variabele beloning in aandelen uit te keren en om deferral toe te passen. De vraag is hoe de Nederlandse wetgever zal omgaan met de proportionele behandeling van beloningen onder de $€ 50.000$ die een derde van de vaste beloning op jaarbasis bedragen, aangezien het Nederlandse bonusplafond gesteld is op 20\%. Volgens de huidige tekstvoorstellen is afwijking door lidstaten mogelijk "because of national market specificities in terms of remuneration practices or because of the nature of the responsibilities and job profile of those staff members'.

Overigens heeft de Europese Commissie eind 2017 voorstellen gepubliceerd voor een nieuw prudentieel kader voor bepaalde beleggingsondernemingen, die beter zijn afgestemd op het businessmodel en de risico's van deze beleggingsondernemingen dan CRD IV/CRR. De voorstellen bevatten ook regels omtrent beloningen. Het strekt te ver om die voorstellen hier nog te behandelen. ${ }^{30}$

\section{Conclusie}

Een deel van de politieke initiatieven die we het afgelopen jaar hebben gezien, sluit niet direct aan bij de uitkomsten van de evaluatie van de Wbfo, wat de indruk wekt dat vooral sprake is van incidentgedreven symboolpolitiek. De uitkomsten van de evaluatie van de Wbfo bieden geen concrete of urgente aanleiding voor de hiervoor besproken nieuw aangekondigde regels met betrekking tot de vaste beloning. De introductie van het merendeel van de besproken nieuwe maatregelen creëert vooral een onnodige extra laag regels en waarschijnlijk ook een schijnveiligheid. De nieuwe regels omtrent de niet-cao-uitzondering (Agenda 
financiële sector) en proportionaliteit (CRD V) zijn vanuit juridisch perspectief toe te juichen, omdat deze tenminste meer duidelijkheid scheppen.

Onder de huidige regelgeving bestaan reeds tal van instrumenten - bijvoorbeeld verplichtingen omtrent KPIs - waarmee, indien goed toegepast en uitgevoerd, financiële ondernemingen een cultuuromslag kunnen bewerkstelligen en geen uitkeringen kunnen doen die de soliditeit van de ondernemingen in gevaar brengen. Ik sluit mij aan bij de opmerking van de Raad van State ${ }^{31}$ dat indien politici het op zichzelf wezenlijke vraagstuk van beloningen en inkomen aan de orde willen stellen, dit een andere aanpak vergt dan we nu zien. Het vereist een bredere maatschappelijke discussie, niet een opstapeling van incidentgedreven rammelende wetsvoorstellen die de concurrentiepositie van Nederland verslechten. Mocht er wel worden overgegaan tot (nog) meer regulering, dan is te hopen dat de wetgever zijn werk grondig doet en wordt voorkomen dat de rechter de put moet dempen, nadat het kalf verdronken is.

31 Kamerstukken II 2017/18, 34906, 4 (Advies Afdeling advisering van de Raad van State en reactie van de initiatiefnemers). 